\title{
INTERNETOVÝ VIRÁLNY MARKETING - MODERNÁ METÓDA ZÍSKAVANIA ZÁKAZNÍKOV
}

\author{
Radovan Madleňák*
}

\section{Úvod}

Je možné propagovat' produkty tak, aby takmer všetko za vás urobili sami spotrebitelia? Prostredníctvom virálneho marketingu to ide...

Táto koncepcia na prvý pohl'ad prevratného marketingového nástroja má svoje korene hlboko v minulosti. Je založená na verbálnom prenose správy, čo predstavuje dobrú a osvedčenú metódu. „Šuškanda“ úspešne predávala a predáva skoro všetko, od filmov a kníh až po technológie vyhl'adávačov. Modernizovala sa iba však iba cesta prenosu. Čo najviac odlišuje virálny marketing od princípu "pošli to d’alej", je jeho zásah, presahujúci obvykle hranice mesta alebo štátu, pričom sa mení aj obsah správy. Tradičné odporučenie produktu alebo služby dnes často nahradzuje multimediálny súbor.

\section{História}

Popularita virálneho marketingu, ktorého prídavné meno autori termínu odvodili od postrachu sveta informačných technológii, je záležitost'ou posledných rokov. Marketéri, povzbudení úspechom niekol'kých akcií, začali tlačit' na svoje komunikačné agentúry, aby ich kampane obohatili práve o prvky "samošíritel'nosti". Ved' čo je lepšie, než spontánne predávaná správa, zaplavujúca elektronickú poštu rýchlost'ou blesku? A tak si užívatelia internetu posielajú vtipné slogany s reklamou na napr. potravinársky koncern alebo humorné fotografie, propagujúce predovšetkým ich autora.

Virálny marketing sa stal známym v roku 1998, ked’ nové tzv. hotmailové služby získali viac ako 12. mil. užívatel’ov. Virálny marketing sa stal medzi marketérmi populárny, predovšetkým kvôli svojej jednoduchosti a nízkonákladovosti. Namiesto náročnej prípravy marketingovej kampane, tu zrazu bola možnost' poslat' niečo atraktívne cez internet, alebo niekol'kým priatel'om cez e-mail a nechat' spotrebitel'ov, nech pracujú za vás.

\section{Definícia}

Virálny marketing možno definovat' ako schopnost' získat' zákazníkov tak, aby si sami medzi sebou povedali o danom výrobku, službe alebo webovej stránke. Iná definícia hovorí, že virálny marketing použiva efektnú ponuku, prenášanú pomocou l’udského ret’azca, za účelom dosiahnutia maximálnej pozornosti a minimalizácie nákladov. Cielom je zvýšenie predaja, rozširenie obchodného potenciálu a budovanie povedomia o značke.

V tejto súvislosti sa tiež používa termín ako „pass-along“ teda predávanie alebo „friend-tell-a-friend“" marketing.

\footnotetext{
* Ing. Radovan Madleňák, PhD., Katedra spojov, Fakulta prevádzky a ekonomiky dopravy a spojov, Žilinská univerzita v Žiline, Univerzitná 1, 01026 Žilina, Slovenská republika, tel.: $+421 / 41 / 5133124$, fax: $+421 / 41 / 5655615$, e-mail: Radovan.Madlenak@fpedas.utc.sk
} 


\section{Princíp činnosti}

Virálny marketing podporuje akúkol'vek stratégiu, ktorá bude povzbudzovat' jednotlivca k tomu, aby predával obchodnú správu d’alším osobám a tým vytváral kapacitu pre exponenciálny nárast zviditel'ňovania správ a ich vplyvu. Rovnako ako v prípade vírusov získavajú takéto stratégie výhodu $\mathrm{z}$ rýchleho násobenia a rozširovania správ $\mathrm{k}$ tisícom a miliónom účastníkov.

Aby mohol virálny marketing dobre fungovat', je potrebné vymysliet' zaujímavé kreatívne riešenie, ktoré príjemcov nielen osloví, ale bude mu pripadat' natol'ko zábavné a zaujímavé, že ich pošle svojím známym. Takto poňatý koncept má vel'kú výhodu v rýchlosti zásahu a elektronická pošta je $\mathrm{v}$ tomto zmysle ideálnym nástrojom. Aby bol virálny marketing úspešný, musia sa brat' do úvahy nasledujúce hl'adiská:

1. Virálny obsah: Základom je nápaditá myšlienka s vel'kým kreatívnym potenciálom. Záleží ale aj na stvárnení a vol'be vhodného formátu (text, audio, video a pod).

2. Násada: Identifikácia webových stránok, ale i konkrétnych l'udí, ktorí sú náchylní k virálnemu správaniu.

3. Spätná väzba: Na základe vyhodnotenia efektivity kampane v závislosti od zvoleného nápadu a typu násady je možné nájst' optimálne kombinácie, ktoré na danom segmente zaručene fungujú.

\section{Formy virálneho marketingu}

Rozoznávame pasívnu a aktívnu formu virálneho marketingu. Pasívna sa spolieha len na pozitívne vyjadrenia zákazníka nijakým spôsobom sa nesnaží jeho správanie ovplyvňovat', zostáva teda na úrovni snahy vyvolat' pozitívnu reakciu ponukou kvalitného výrobku alebo služby. Aktívna forma virálneho marketingu spočíva v tom, že firma sa pomocou virálnej správy snaží ovplyvnit' správanie zákazníka a zvýšit' tak predaj výrobku, či povedomie o značke. Za virálnu správu možno považovat' posolstvo s reklamným obsahom, ktoré je pre osoby, ktoré s ním prídu do kontaktu natol'ko zaujímavé, že ho samovol'ne a vlastnými prostriedkami šíria d'alej.

V prípade aktívneho virálneho marketingu, najčastejšou formou prenosu je e-mail, odosielaný $\mathrm{z}$ poštového klienta jednej osoby na d’alšie adresy. Druhým najčastejšie využívaným prvkom virálneho marketingu sú webové stránky. Odborná literatúra definuje viacero techník virálneho marketingu:

1. Preposielanie: K šíreniu správy je využitý samotný e-mail. Pretože prví adresáti dali firme súhlas k zasielaniu komerčných ponúk, nejedná sa o SPAM. Následné aktivity sa odohrávajú $\mathrm{v}$ rovine bežnej korešpondencie medzi príbuznými, priatel'mi alebo kolegami. Doterajšie skúsenosti hovoria, že najväčšiu mieru penetrácie dosahujú multimediálne súbory. E-mail ich pritom nemusí obsahovat' vo forme prílohy, často stačia odporúčania na webové stránky, kde je „marketingový vírus“ $\mathrm{k}$ dispozícii.

2. E-mail výzva: E-mail obsahuje odkaz na webové stránky s možnost'ou odoslania správy priatel'om. Okrem avizovaného „vírusu“ - prezentácie, získa adresát taktiež reklamnú informáciu.

3. Výzva na webe: Jedná sa o rovnaký princíp ako pri e-mailovej výzve, s tým rozdielom, že výzva $\mathrm{k}$ vytvoreniu e-mailu je priamo súčast'ou multimediálnej reklamnej prezentácie.

4. Virálny web-link: Je dôležité si uvedomit', že autor nemusí byt' limitovaný na služby elektronickej pošty. Umiestnenie (úmyselne nastraženého) odkazu do zaujímavého článku alebo diskusie často prinesie podobný efekt. Tu však často dochádza k zámene 
virálneho marketigu s "on-line public relations". Samotný úspech tejto formy virálneho marketingu významne závisí na kreativite prvotnej a následnej informácie (čo sa zobrazí po kliknutí na odkaz), rovnako ako na vhodnosti miesta násady.

\section{Faktory úspechu virálneho marketingu}

Odborníci, ktorí sa zaoberali analýzou dopadu virálneho marketingu, sa zhodli na skupine klúčových atribútov, ktoré obsahovala väčšina úspešných virálnych koncepcií:

$>$ Objekt záujmu musí byt' bezplatný

Šírenie informácií o predmetoch, ktoré sa kupujú, je ovel'a t’ažšie. Výnimkou môže byt' tovar, ktorý je netrpezlivo očakávaný alebo ktoré sprevádza pôsobivý príbeh. Ako by asi dopadol klasický príklad virálneho marketingu, projekt Hotmail.com, ak by sa pri registrácii e-mailovej schránky platilo?

$>$ Prenášanie správy nesmie byt komplikované

Na prenášanie predpripraveného balíčka (s virálnym obsahom vo vnútri) je vhodné použit' dôverne známy prostriedok, napríklad e-mail. Ponuky typu "upozorni známeho" nie sú na rýchly prenos príliš vhodné, zatial' čo napríklad videohra, flash animácia alebo URL adresa sa prenáša medzi účastníkmi ovel’a rýchlejšie.

> Správa musí byt' zaujímavá, vtipná alebo hodnotná Váš odkaz musí byt' pre publikum určitým spôsobom prít’ažlivý. Inak ho samozrejme nikto nebude posielat' d'alej.

$>$ Preposielanie nie je spojené sodmenou

Pokial' má virálny marketing pôsobit' dôveryhodne, je striktne žiadané spontánne správanie. Š́renie správy nesmie byt' spojené s žiadnou finančnou odmenou. Každý pokus o prelomenie tejto bariéry prináša otázky a problémy pri vyhodnocovanie reálneho záujmu o propagovaný produkt.

\section{Príklady využitia virálneho marketingu}

\section{Budovanie povedomia o značke}

Klasickým príkladom úspešného virálneho projektu bol projekt anglickej spoločnosti VIRGIN, ktorá prostredníctvom dvadsiatich piatich vytipovaných osôb ponúkla dva vol'né lístky do divadla. Ozvat' sa mohli všetci príjemcovia uvedenej správy. V priebehu troch hodín sa vypredalo (odovzdalo) všetkých 20000 pripravených vstupeniek. Nešlo pritom o investíciu do vstupného, tá bola zanedbatel'ná, vzhl'adom na to, že spoločnost' VIRGIN si mohla objednat' na zvýšenie imidžu napr. vzducholod' nad Temžou alebo celostránkový inzerát v najpredávanejšom anglickom denníku. Ale určite by nemohla počítat' s podobným ohlasom, záujmom verejnosti a médií, ako $\mathrm{v}$ tomto prípade. Je možné teda bez žiadnych pochýb konštatovat', že virálny marketing významne pomáha $\mathrm{v}$ procese budovania povedomia o značke.

\section{Podpora predaja}

Existuje viacero spôsobov ako si vypomôct' s virálnym marketingom pri podpore predaja produktov. Je nutné však povedat' že neexistuje, žiadna priama súvislost' medzi virálnym marketingom a predajom. Nasledujúce príklady ukazujú iba možnost' prepojenia predaja a techník virálneho marketingu.

$>$ Dve sady produktov

Čast' výrobkov je ponúkaná zadarmo, ale tie nespíňajú kritéria rozšírenej platenej plnej verzie. Je vhodné ponúknut' napríklad bezplatný dvojstránkový redakčný výber a zároveň plnohodnotný elektronický časopis s množstvom zaujímavých článkov. Nebezpečenstvo použitia dvoch typov výrobkov spočíva $\mathrm{v}$ nesprávnom umiestnení hranice, za ktorou sa nachádza spoplatnený obsah. Pokial' sa ponúkne čitatel'om 
redakčného výberu všetko, čo by ich mohlo zajímat', nebudú sa potom obt'ažovat' objednávaním plnej verzie časopisu.

$>$ Reklamný darček

Predajca záhradnej techniky zašle s predchádzajúcim súhlasom na pár zákazníckych adries špeciálnu ponuku. V e-maile je odkaz na webovú prezentáciu, kde je možné bezplatne získat' jeden $\mathrm{z}$ pripravených reklamných balíčkov so semiačkami. Návštevníci sú zároveň vyzvaní, aby o tejto službe referovali známym. Vybrané semiačka potom dealer expeduje s priloženými aktuálnymi katalógmi napr. kosačiek na trávu.

$>$ Diskontný systém

Čo ak predajca deklaruje nadštandardnú zl’avu za získanie d’alšieho záujemca? Model síce využíva zákony multi-level predaja, ale uberá sa úplne neškodným spôsobom. Pokial' si Vami oslovený potenciálny klient skutočne niečo objedná, pomôže Vám k výrazne lepšej cene. Táto forma využitia virálneho marketingu pri podpore predaja je vel'mi účinná a funguje aj v elektronickej podobe. Jej výhodou je, že na jej realizáciu nie je potrebný vo firme žiaden nový zamestnanec.

\section{Hlavné obmedzenia virálneho marketingu}

Nebezpečenstvo virálneho marketingu je hlavne v tom, že po jeho odštartovaní nemá už marketér možnost' kontroly nad tým, ako sa marketingový vírus d'alej šíri. To znamená, že nie je vhodné sl'ubovat' bez obmedzenia darčeky, ako je to niekedy napr. pri online prieskumoch. Ako negatívny príklad možno uviest' kampaň, ked' jeden marketér rozoslal výzvu na zapojenie sa do prieskumu, v rámci ktorého ponúkal odmenu, do 25 verejných webových stránok. Kampaň sa ale privel'mi rozprúdila a vymkla sa kontrole. Zrazu mal viac ako 15-tisíc l'udí reagujúcich na prieskum a požadujúcich bezplatné tričká a poukážku na darček.

Je však potrebné povedat', že asi najväčším nepriatel’om legálneho virálneho marketingu je SPAM, teda nevyžiadaná elektronická pošta. A to hlavne preto, že môže dochádzat' $\mathrm{k}$ ich zámene. Najväčším pôvodcom SPAM-u sú USA. Plných 42,1\% SPAM-u pochádza zo Spojených štátov. Nasleduje Južná Kórea s 13,43 \%, Č́na $(8,44 \%)$, Kanada $(5,71 \%)$, Brazília $(3,34 \%)$ a Japonsko (2,57 \%). Európske štáty ako Vel'ká Británia, Francúzsko či Španielsko prispievajú zdruba jedným percentom, rovnako ako Taiwan či Mexiko. Podl'a správy agentúry Sophos sa tak ukazuje, že legislatívne pokusy obmedzit' SPAM nemajú žiadny praktický vplyv. Viac ako 40 \% svetového SPAM-u majú na svedomí počítače ovládnuté hackermi, či vírusmi. Preto sa marketéri, ktorí využívajú web ako legálny priestor pre komunikáciu so spotrebitel'mi a potenciálnymi zákazníkmi, snažia podporit' celosvetový boj proti SPAM-u.

Ak teda marketéri chcú využívat' túto marketingovú metódu a nechcú aby ich reklamná kampaň nebola spájaná so SPAM-ovými aktivitami, mali by dodržiavat' všeobecne platné etické zásady:

$>$ Zasielat' komerčnú elektronickú poštu iba adresátom, od ktorých získal súhlas $\mathrm{k}$ takémuto konaniu.

$>$ Dat' každému adresátovi možnost' vymazania sa $\mathrm{z}$ mailingového zoznamu odosielatel'a.

> Nezasielat’ zbytočnú a nepotrebnú elektronickú poštu ani tam, kde bol k tomu získaný súhlas.

$>$ Komerčný e-mail vždy podpísat' menom konkrétnej osoby, s uvedením rôznych možností kontaktu na ňu.

$>$ Elektronickú komerčnú správu odosielat’ z jasne identifikovatel'nej adresy. 


\section{Záver}

Virálny marketing je jednou z najnevypočítatel'nejších a najzáhadnejších marketingových metód. Stále ešte nie je jasné, či ide len metódu na jedno použitie alebo o niečo, s čím sa bude zákazník, najmä na internete, stretávat' na každom kroku. Aj preto je dôležité zamysliet' sa nad účinnost'ou, výhodami a nevýhodami tejto zatial' málo obvyklej marketingovej metódy.

Hlavnou výhodou virálneho marketingu je nízkonákladovost' jeho kampaní a ich realizácia v krátkom čase, oproti klasickým kampaniam vyžadujúcim klasické výrobné technológie. To so sebou nesie vysokú akcieschopnost', ktorá môže byt' častokrát kl'účová. Nevýhodou je malá kontrola nad vlastnou kampaňou. Po štarte virálnej kampane, už vírus žije vlastným životom a šíri sa podl'a vôle príjemcov. Je to ale zbraň, ktorá priamo vyzýva k premyslenému použitiu, pretože práve ona dokáže vyvolat' obrovskú odozvu zo strany spotrebitel’ov, ktorí sú stále viac imúnni ku klasickým formám marketingovej komunikácie.

\section{Literatúra}

[1] ČOREJOVÁ, T.: K problematike cenových modelov v elektronických komunikačných službách. In: marketing a obchod 2004. Rok európskej integrácie. Zborník z medzinárodnej vedeckej konferencie, Zvolen 2004, ISBN 80-89100-20-1

[2] HLAVENKA, J.: Internetový marketing. Computer Press, Praha, 2001. ISBN 80-7226498-2

[3] KREMEŇOVÁ, I., ROSTÁŠOVÁ, M.: Marketing $\mathrm{v}$ službách : Marketingový informačný systém, 1. vyd. - V Žiline : Žilinská univerzita, 2005. - 110 s., AH 6,95, VH 7,28 : obr., tab. - ISBN 80-8070-358-2.

[4] MADLEŇÁK, R: Elektronický obchod, Žilinská univerzita v Žiline, Žilina, 2004, 160 str., ISBN 80-8070-192-X

[5] ŠVADLENKA, L.: Marketing v poštovních službách, První vydání. Univerzita Pardubice, 2006. ISBN 80-7194-714-8.

[6] VACULÍK, J.: Marketing v prostredí internetu, In: Zborník príspevkov z medzinárodnej vedeckej konferencie KIT 2003, 26.-28. november 2003, Liptovský Mikuláš, Vojenská akadémia, 2003, ISBN 80-968711-4-5, s. 7-11.

[7] http://www.interval.cz

\section{Grantová podpora}

1/1265/04 VEGA MŠ SR a SAV - Výskum siet’ových procesov v rámci odvetvových zoskupení firiem SR

1/2591/05 VEGA MŠ SR a SAV - Vplyv výberu efektívnej stratégie na udržiavanie konkurencie schopnosti podniku v rámci liberalizácie poštových trhov 